\title{
Proteolysis and orientation in Dictyostelium slugs
}

\author{
J. T. BONNER* \\ Department of Ecology and Evolutionary Biology, Princeton University, Princeton, New Jersey 08544, USA
}

(Received 11 January 1993; revised 25 April 1993; accepted 25 June 1993)

\begin{abstract}
It has been long known that the migrating slugs of the cellular slime moulds are highly sensitive to their environment and orient towards light and in temperature and chemical gradients. There is considerable evidence from past work that these orientations are governed by $\mathrm{NH}_{3}$ which affects the rate of movement of cells within the slug with such precision that orientation to the external stimuli is achieved. In order to test this hypothesis further, various ways to alter the internal $\mathbf{N H}_{3}$ concentration were devised. Substances that either increased or decreased proteolysis were applied to one side of the tip of a slug, thereby affecting its orientation. Some of the treatments strongly support the role of internally produced $\mathrm{NH}_{3}$ in orientation, and all the treatments produce results that are consistent with the hypothesis.
\end{abstract}

\section{Introduction}

In recent years we have been accumulating evidence that orientation in the migrating slugs and rising cell masses of cellular slime moulds is governed by the internal concentration of $\mathrm{NH}_{3}$ within the mass. First it was shown that the application of minute amounts of external $\mathrm{NH}_{3}$ gas repels the slugs (Bonner et al., 1986; Feit \& Sollitto, 1987; Kosugi \& Inouye, 1989) and therefore the volatile orienting substance described much earlier (Bonner \& Dodd, 1962) is probably $\mathrm{NH}_{3}$. It was presumed that it did this by speeding up the cells on the side of the slug, or rising sorogen, which was surrounded by a higher concentration of $\mathrm{NH}_{3}$, with the result that the cell mass moved away from the $\mathrm{NH}_{3}$. More recently we have shown by measuring slug speed, and the speed of separate, preaggregation amoebae, that there is an optimal concentration of $\mathrm{NH}_{3}$ which makes the slugs and the cells move faster, while at higher concentrations the speed is inhibited (Bonner et al., 1989). As Kosugi \& Inouye (1989) and Van Duijn \& Inouye (1991) have shown, there is evidence that these effects of $\mathrm{NH}_{3}$ are due to changes in the internal $\mathrm{pH}$ of the cells, for $\mathrm{NH}_{3}$ penetrates cells rapidly and raises their $\mathrm{pH}$. It has been suggested that the striking ability of slime mould cell masses to orient towards light might be explained by the fact that light increases the internal $\mathrm{NH}_{3}$ production, and because of the 'lens effect' the far side will be more

\footnotetext{
* Tel. +1 (609) 2583841 ; fax +1 (609) 2581712.
}

illuminated than the near (Bonner et al., 1988). We have also tried to explain orientation in heat gradients in terms of internal $\mathrm{NH}_{3}$ production, but here the evidence becomes more tenuous because, depending upon the ambient temperature, there may be either a positive or a negative thermotaxis (Whitaker \& Poff, 1980) and therefore the hypothesis requires more assumptions. Since it is clear that $\mathrm{NH}_{3}$ production within the slug might play a role in orientation, I decided to try to find ways of directly influencing the $\mathrm{NH}_{3}$ production which, in turn, should affect orientation. As will be evident, all of the experiments reported here are consistent with the $\mathrm{NH}_{3}$ orientation hypothesis, although some provide far more compelling evidence than others.

\section{Methods}

The spores of Dictyostelium discoideum (strain NC-4) were placed on a mound of Escherichia coli $\mathrm{B} / \mathrm{r}$ made by plunging a loopful of bacteria into $2 \%(\mathrm{w} / \mathrm{v})$ non-nutrient agar in three spots on a Petri dish, thereby providing plenty of room for the migration of the slugs. All the culturing and experiments were done at room temperature. The experiments were recorded on videotape taken through a $50 \mathrm{~mm}$ lens attached through a microscope to a Panasonic video camera (WV1850 ) with time lapse (AG-6720A).

Chemicals. The activated charcoal used was Darco G-60 (Fisher Scientific Co.) The papain came in a lyophylized form (Sigma). All the protease inhibitors used were the water-soluble ones in a protease inhibitor kit (Boehringer Mannheim) which was given to me through the generosity of Dr D. Fong (Rutgers Univ., Piscataway, NJ, USA).

The hydrolysed polyacrylamide ('Hypa') beads were kindly supplied by Drs M. S. Steinberg and J. Drawbridge (Princeton Univ.) following the method of preparation of Zackson \& Steinberg (1989). The beads were soaked in the test solutions from $15 \mathrm{~min}$ to $1 \mathrm{~h}$. 


\section{Results and Discussion}

\section{Activated charcoal}

Before considering proteolysis and orientation, I would like to report one experiment suggested to me by Kei Inouye which supports the role of $\mathrm{NH}_{3}$ in orientation. It has been known for many years that slime mould cell masses will orient towards charcoal (Bonner \& Dodd, 1962) presumably because the charcoal absorbs and therefore removes the repellent gas (Fig. 1a). If the charcoal is first placed in an atmosphere of high $\mathrm{NH}_{3}$ in

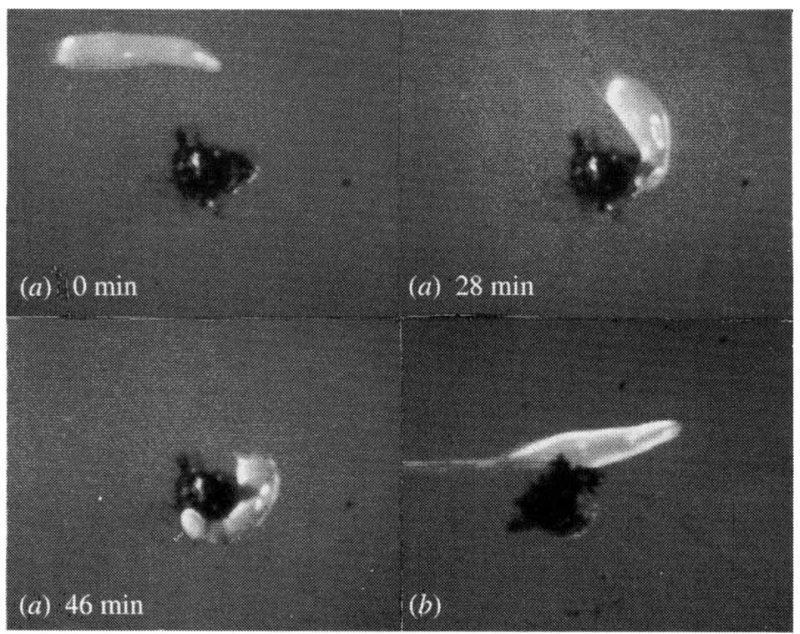

Fig. 1. Effect of charcoal on the orienting of slugs of $D$. discoideum. (a) A pile of Darco G-60 attracts a slug from a distance. (The numbers indicate the time in minutes.) (b) Here the Darco G-60 has been in an atmosphere of concentrated $\mathrm{NH}_{3}$ for $3 \mathrm{~d}$, and has entirely lost its ability to attract the slug, even when it is initially placed near the tip.

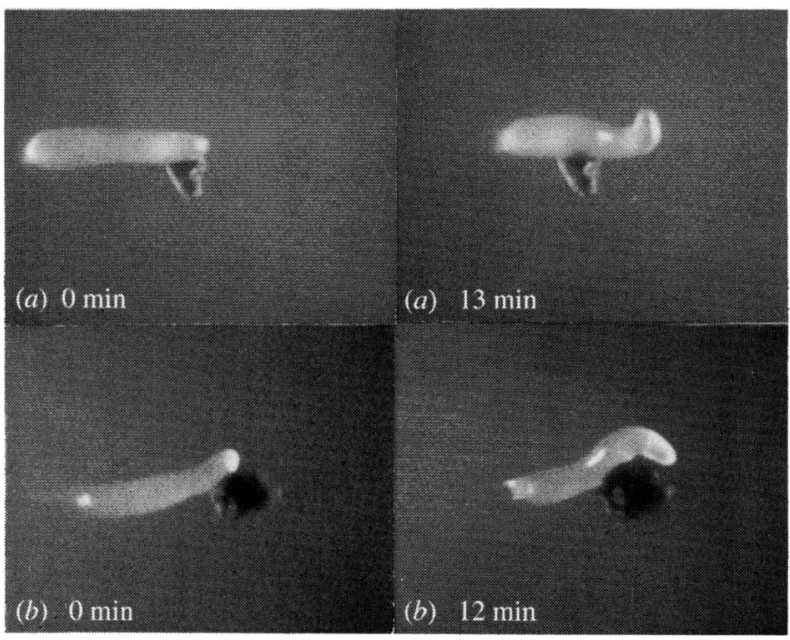

Fig. 2. Effect of protease and protease inhibitors. (a) A polyacrylamide bead saturated with a solution of papain is placed near the tip of a slug, and after a delayed response the tip moves away from the side where the protease was originally placed. (b) A mixture (Boehringer Mannheim) of protease inhibitors was similarly placed in a bead on one side of the tip of a slug, and the slug curls around the bead. Proteolysis increases the speed of the tip, and inhibitors of proteolysis decrease their speed.
Table 1. Effect of different treatments applied to the tip of a slug that cause the slug to either turn away or towards the treated side

\begin{tabular}{lccc}
\hline \hline & & \multicolumn{2}{c}{ No. of slugs that: } \\
\cline { 3 - 4 } Treatment & Concn & $\begin{array}{c}\text { Turn } \\
\text { away }\end{array}$ & $\begin{array}{c}\text { Turn } \\
\text { towards }\end{array}$ \\
\hline Papain & $5.5 \mu \mathrm{g} \mathrm{m}^{-1}$ & 10 & 0 \\
Wounding & & 11 & 1 \\
Acid Dowex 50 & & 24 & 2 \\
Antipain & $50 \mu \mathrm{g} \mathrm{ml}^{-1}$ & 0 & 6 \\
Phosphoramidon & $300 \mu \mathrm{gl}^{-1}$ & 0 & 7 \\
Ethanol & $3-30 \%(\mathrm{v} / \mathrm{v})$ & 0 & 7 \\
\hline \hline
\end{tabular}

a desiccator jar (over a mixture of $20 \mathrm{ml} 30 \%$ (w/v) $\mathrm{NH}_{4} \mathrm{Cl}$ and $50 \mathrm{ml} 1 \mathrm{M}-\mathrm{NaOH}$ in a well) for at least $2 \mathrm{~d}$ or more, and then tested by being placed close to a migrating slug, the charcoal will have no effect on the orientation of the slug at all (Fig. 1b). In other words, if the charcoal is saturated with $\mathrm{NH}_{3}$ it is no longer capable of attracting the slug; it can no longer remove the $\mathrm{NH}_{3}$ in the atmosphere on one side of the slug.

Another way of testing activated charcoal is to measure the speed of a migrating slug before and after it has been sprinkled lightly with fresh charcoal. In 24 cases the mean speed before treatment with charcoal was $2 \cdot 10 \mathrm{~mm} \mathrm{~h}^{-1}$, while after dusting the speed slowed to $0.78 \mathrm{~mm} \mathrm{~h}^{-1}$. [The difference is significant at a level of $P=0.0001$ in a paired (one-tailed) $t$-test.]

\section{A proteolytic enzyme}

In these experiments a hydrolysed polyacrylamide ('Hypa') bead was soaked in a protease solution after which it was placed on one side of the tip of a migrating slug. If papain $\left(5.5 \mathrm{mg} \mathrm{ml}^{-1}\right)$ was used, after 2 to $10 \mathrm{~min}$ the slug tip would take a sharp turn away from the side where the bead was placed (Fig. $2 a$; Table 1). Because it was known from previous work that papain digested the slime sheath (Whitfield, 1964; Takeuchi \& Yabuno, 1970 ) it is reasonable that in the experiment here the papain caused proteolysis in a localized region of the slime sheath. This in turn resulted in a liberation of $\mathrm{NH}_{3}$ on one side of the slug, causing the cells on that side to move faster, with the result that the slug tip turned away from the bead. If the bead is put in place for as little as $3 \mathrm{~min}$ and then removed, the turning effect occurs. Once the $\mathrm{NH}_{3}$ is made it will diffuse rapidly. It must be remembered that turning can only occur at the tip and the rest of the slug follows, and therefore only the proteolysis that takes place at one side of the tip can have any effect. 


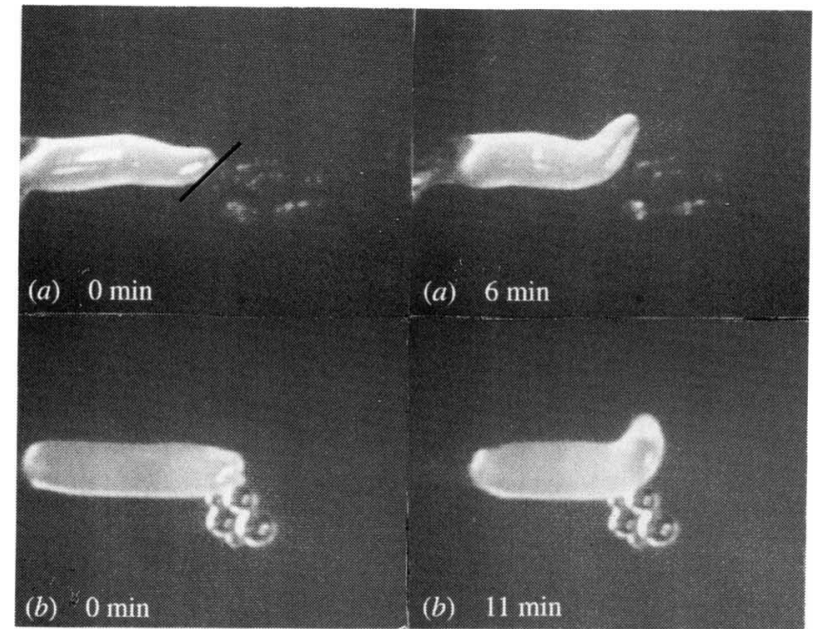

Fig. 3. Effect of wounding and acid. (a) The side of a tip of a slug has been sliced off with a glass needle and the tip moves away from the cut side. (b) If Dowex 50 beads (which are acidic) touch one side of the tip, the tip moves away.

\section{Wounding}

If a slug is cut on one side of the tip, or if the cells on that side are disrupted with a fine glass needle, the tip will abruptly turn away from the wound (Fig. $3 a$; Table 1). One might have imagined that such a localized trauma would cause a decrease in the speed of movement at the site of the wound, but the reverse is true. It is well known that in mammals there is an increase in proteolytic activity at wound sites (review: Raekallio, 1970), and conceivably slime moulds respond the same way. This interpretation is supported by the fact that if charcoal (Darco G-60) is added immediately after the cut is made, the slug is not affected by the cut and wraps itself around the charcoal. This is presumably because the charcoal removes all the $\mathrm{NH}_{3}$, including the $\mathrm{NH}_{3}$ generated by the proteases in the wound.

\section{Acid}

Another factor which seems to have a profound effect on the rate of cell movement is $\mathrm{pH}$. When slugs crawl over agar of different $\mathrm{pH}$ values, the more acid the agar the faster they will move. This was shown in two ways: the slugs were allowed to crawl onto small Nuclepore membranes, and these membranes were first placed over buffered agar of one $\mathrm{pH}$ and then another. Similar results were obtained when groups of slugs crawled directly on buffered agar of different $\mathrm{pH}$ values. (If the various results are grouped, the mean speed of slugs at $\mathrm{pH} 5.5$ is $1.47 \mathrm{~mm} \mathrm{~h}^{-1}+\mathrm{SD} 0.19, n=18$; at $\mathrm{pH} 8.5$ the speed is $1.20 \mathrm{~mm} \mathrm{~h}^{-1}+\mathrm{SD} 0.12, n=8$. Using a two-tailed $t$-test, the difference is significant at the $P=0.001$ level.)

The effect can be shown dramatically with the use of ion exchange beads. If an acid Dowex 50 bead is placed on the side, near the tip of a slug, the tip will rapidly move away from the bead: the cells near the point where the bead touches move faster than those on the opposite side (Fig. $3 b$; Table 1). This is true if the bead is first treated with $\mathrm{HCl}, \mathrm{NaOH}$ or $\mathrm{NH}_{4} \mathrm{Cl}$. That this effect is due to the acid is supported by various controls, such as basic Dowex 1 beads, or glass chips which do not affect the slug orientation in any way whatsoever when they are similarly placed on the side of a slug tip.

There is the question of why an acid environment would cause cells to move more rapidly. The low $\mathrm{pH}$ of the substrate surface is unlikely to affect the $\mathrm{pH}$ within the cells as Kay et al. (1986) have shown. One possibility is that there are proteases in the slime sheath among the many different proteins Smith \& Williams (1979) found there, and lowering the $\mathrm{pH}$ at the contact surface might be more favourable for inducing their proteolytic activity. Furthermore, it is known that slime moulds secrete proteases in large quantities and they are acid proteases, with highest activity at low pH values (North \& Harwood, 1979; North, 1982).

\section{Protease inhibitors}

To perform the mirror image of the above experiments, various proteolytic-enzyme inhibitors were allowed to be soaked up by the polyacrylamide beads and applied to the tips of migrating slugs in the same manner as with papain above. If a mixture of five different water-soluble inhibitors was used the slugs bent around the bead; clearly the inhibitors were slowing the cells on the side to which were applied (Fig. $2 b$ ). When they were tested singly it was found that antipain $\left(50 \mu \mathrm{g} \mathrm{ml}^{-1}\right)$ and phosphoramidon $\left(300 \mu \mathrm{g} \mathrm{ml}^{-1}\right)$ were active (Table 1) while leupeptin $\left(0.5\right.$ and $\left.1.0 \mu \mathrm{g} \mathrm{ml}^{-1}\right)$, EDTA-Na $(0.5 \mathrm{mg}$ $\mathrm{ml}^{-1}$ ) and APMSF (4-amidinophenylmethanesulphonyl fluoride; $40 \mu \mathrm{g} \mathrm{ml}^{-1}$ ) had no effect. Since the first two inhibitors differ in the kinds of protease they affect (phosphoramidon is a metalloprotease inhibitor and antipain inhibits cysteine- and serine proteases, and since some of the inhibitors that did not work do inhibit the same type of proteases, I suspect the reason for success or failure is due simply to which ones manage to diffuse readily into the cells.

\section{Ethanol}

In testing an enzymic method for removing $\mathrm{NH}_{3}$ [a mixture of 2-oxoglutarate, NADH and glutamate dehydrogenase - first used by Schindler \& Sussman (1977) for slime moulds], I found that the slugs curled inwards, towards the bead, as was expected. It was also possible to show that if a drop of the solution was placed on a slug, all migration movement stopped, as Schindler and 
Sussman had discovered. The surprise came upon discovering that the controls with beads containing an NADH solution only also caused slugs to bend around the beads. However, it turned out not to be the NADH but the small amount of ethanol in the NADH preparation. Using beads containing ethanol alone (in concentrations ranging from 3 to $30 \%, v / v)$ it was possible to show a reduction of the speed of the cells on the side touching the bead (Table 1), appearing very much like the slug shown in Fig. 2(b).

Because of the enormous medical interest in the effects of ethanol, it has been known since the last century that proteolysis in the mammalian gut is inhibited by as little as $3 \%$ ethanol and is totally inactivated at a concentration of $20 \%$ (review: Orten \& Sardesai, 1971). Also, ethanol penetrates into all the tissues rapidly by diffusion (review: Kalant, 1971). This is one possible explanation of why ethanol slows the cells - a reduction of internal proteolysis and therefore $\mathrm{NH}_{3}$ production on one side of the slug. Obviously, there are other possible reasons, such as the general effect of ethanol in depressing metabolism (review: Wallgren, 1971).

\section{Conclusion}

All the experiments reported here support the hypothesis that orientation in Dictyostelium slugs is propelled by local differences in the $\mathrm{NH}_{3}$ concentration in the slug tip, and that these differences are brought about by variations in the breakdown of proteins in different areas of the slug.

I would like to thank S. Chiu for technical assistance in the earlier phases of this project. I also thank the following individuals for helpful comments and ideas: E. C. Cox, J. Drawbridge, D. Fong, K. Inouye, $M$. North and two anonymous reviewers.

\section{References}

BONNER, J. T. \& DODD, M. R. (1962). Evidence for gas induced orientation in the cellular slime molds. Developmental Biology 5, 344-361.

Bonner, J. T., Suthers, H. B. \& Odell, G. M. (1986). Ammonia orients cell masses and speeds up aggregating cells of slime molds. Nature, London 323, 630-632.
Bonner, J. T., Chiang, A., Lee, L. \& Suthers, H. B. (1988). The possible role of ammonia in phototaxis of migrating slugs of Dictyostelium discoideum. Proceedings of the National Academy of Sciences of the United States of America 85, 3885-3887.

BonNer, J. T., HAR, D. \& Suthers, H. B. (1989). Ammonia and thermotaxis - further evidence for a central role of ammonia in the directed cell mass movements of Dictyostelium discoideum. Proceedings of the National Academy of Sciences of the United States of America 86, 2733-2736.

FEIT, L. N. \& Sollitro, R. B. (1987). Ammonia is the gas used for the spacing of fruiting bodies in the cellular slime mold. Dictyostelium discoideum. Differentiation 33, 193-196.

KaLANT, H. (1971). Absorption, diffusion, distribution, and elimination of ethanol. In The Biology of Alcoholism, vol. 1, Biochemistry, pp. 1-62. Edited by B. Kessin \& H. Begleiter. New York: Plenum Press.

KAY, R. R., Gadian, D. G. \& WiLliams, S. R. (1986). Intracellular pH in Dictyostelium: a ${ }^{31} \mathrm{p}$ nuclear magnetic resonance study of its regulation and possible role in controlling cell differentiation. Journal of Cell Science 83, 165-179.

KosUGI, T. \& INOUYE, K. (1989). Negative chemotaxis to ammonia and other weak bases by migrating slugs of the cellular slime moulds. Journal of General Microbiology 135, 1589-1598.

NORTH, M. J. (1982). A study of the proteinase activity released by Dictyostelium discoideum during starvation. Journal of General Microbiology 128, 1653-1660.

NoRTH, M. J. \& HARwOOD, J. M. (1979). Multiple acid proteinases in the cellular slime mould Dictyostelium discoideum. Biochimica et Biophysica Acta 566, 222-233.

Orton, J. M. \& Sardesai, V. M. (1971). Protein, nucleotide, and porphyrin metabolism. In The Biology of Alcoholism, vol. 1, Biochemistry, pp. 229-261. Edited by B. Kessin \& H. Begleiter. New York: Plenum Press.

RaEKALlio, J. (1970). Enzyme Histochemistry of Wound Healing, pp. 90-94. Portland: Gustav Fischer Verlag.

SCHINDLER, J. \& SUSSMAN, M. (1977). Ammonia determines the choice of morphogenetic pathways in Dictyostelium discoideum. Journal of Molecular Biology 116, 161-169.

Smith, E. \& Williams, K. L. (1979). Preparation of slime sheath from Dictyostelium discoideum. FEMS Microbiology Letters 6, 119-122.

TAKBUCHI, I. \& YaBUNO, K. (1970). Disaggregation of slime mold pseudoplasmodia using EDTA and various proteolytic enzymes. Experimental Cell Research 61, 183-190.

VAN DUIJN, B. \& INOUYE, K. (1991). Regulation of movement speed by intracellular $\mathrm{pH}$ during Dictyostelium discoideum chemotaxis. Proceedings of the National Academy of Sciences of the United States of America 88, 4951-4955.

WALLGREN, H. (1971). Effect of ethanol on intracellular respiration and cerebral function. In The Biology of Alcoholism, vol. 1, Biochemistry, pp. 103-125. Edited by B. Kessin \& H. Begleiter. New York: Plenum Press.

Whitaker, B. D. \& PoFf, K. L. (1980). Thermal adaptation of thermosensing and negative thermotaxis in Dictyostelium. Experimental Cell Research 128, 87-93.

WhITFIELD, F. E. (1964). The use of proteolytic and other enzymes in the separation of slime mould grex. Experimental Cell Research 36, 62-72.

ZACKSON, S. J. \& STEINBERG, M. S. (1989). Axolotl pronephric duct cell migration is sensitive to phosphatidylinositol-specific phospholipase C. Development 105, 1-7. 